\title{
EDUKASI KHASIAT DAUN SALAM SEBAGAI UPAYA PENINGKATAN PENGETAHUAN IBU RUMAH TANGGA
}

\author{
Shinta Mayasari ${ }^{1}$ \\ ${ }^{1}$ Fakultas Ilmu Kesehatan,Program Studi Farmasi, Jember, Indonesia \\ Email: shintamayasari@uds.ac.id
}

\begin{abstract}
ABSTRAK
Daun salam (Syzygium polyanthum) merupakan salah satu tanaman yang mudah ditemukan di pekarangan rumah, namun masyarakat tidak banyak yang mengetahui akan khasiat tanaman tersebut. Edukasi akan khasiat daun salam sangat penting diberikan kepada masyarakat agar kaya akan pengetahuan khasiat tanaman tersebut. Adapun tujuan pengabdian masyarakat ini adalah memberikan wawasan pengetahuan yang lebih dari daun salam selain digunakan sebagai bumbu dalam kehidupan sehari-hari. Metode yang digunakan dalam pengabdian masyarakat adalah secara daring via online dengan cara berdiskusi dan tanya jawab secara langsung kepada masyarakat khususnya adalah ibu rumah tangga. Hasil yang diperoleh dari kegiatan pengabdian masyarakat adalah ibu rumah tangga memberikan respon terhadap materi yang disampaikan sehingga menjadi lebih mengetahu dan paham akan khasiat daun salam yang selama ini tidak diketahui sebagai tanaman herbal. Dari hasil kegiatan pengabdian masyarakat dapat disimpulkan bahwa terdapat peningkatan pengetahuan khasiat daun salam oleh ibu rumah tangga dengan rerata 96\%, ibu rumah tangga memahami khasiat daun salam selain sebagai bumbu yaitu sebagai tanaman herbal yang mampu mengurangi keluhan dari berbagai penyakit diantaranya adalah diabetes mellitus, asam urat, kolesterol dan sebagainya.
\end{abstract}

Kata Kunci: edukasi, daun salam, ibu rumah tangga.

\begin{abstract}
Bay leaf (Syzygium polyanthum) was one of the plants that was easily founded in the yard of the house, but not many people knowed about the benefits of this plant. Education about the efficacy of bay leaves was very important to give to the public so that they were rich in knowledge of the efficacy of these plants. The purpose of this community service was to provide insight into knowledge that was more than bay leaves besides being used as a spice in everyday life. The method used in community service was online via online by discussing and asking questions directly to the community, especially housewives. The results obtained from community service activities are that housewives respond to the material presented so that they become more aware and understand the efficacy of bay leaves which have not been known as herbal plants. From the results of community service activities, it cold be concluded that housewives become more aware of and understand the efficacy of bay leaves other than as a spice, namely as a herbal plant that could reduce complaints from various diseases including diabetes mellitus, gout, cholesterol and so on.
\end{abstract}

Keywords: education, bay leaf, housewife. 


\section{PENDAHULUAN}

Daun salam (Syzygium polyanthum) merupakan salah satu tanaman yang banyak dijumpai di pekarangan rumah, pegunungan dan di desa. Masyarakat banyak menggunakan daun salam sebagai bumbu masakan dalam kehidupan sehari-hari. Daun salam tidak hanya digunakan sebagai bumbu masakan namun juga bisa digunakan sebagai tanaman obat. Masyarakat membutuhkan edukasi dalam hal penggunaan khasiat penggunaan tanaman obat. Edukasi diberikan kepada masyarakat dengan tujuan untuk mengedukasi ilmu dan wawasan yang luas kepada masyarakat dengan harapan menjadi paham akan ilmu dan bisa menerapkan ilmu tersebut dalam kehidupan sehari-hari (Nurdiwaty et al. 2017). Kandungan dari daun salam diantaranya adalah minyak atsiri, tannin dan flavonoid (Wirawan 2018).

Berdasarkan penelitian yang dilakukan oleh peneliti sebelumya, daun salam dapat digunakan sebagai antihipertensi, antidiabetes, antihiperkolesterol, antioksidan, antidiare, antibakteri dan mengatasi asam urat. Nilai lebih dari daun salam akan bermanfaat untuk masyarakat selain sebagai bumbu masakan. Khasiat dari daun salam bisa digunakan secara langsung dari yang berbentuk daun segar, simplisia dan dalam bentuk ekstrak. Masyarakat khususnya ibu rumah tangga perlu diedukasi untuk mendapatkan ilmu yang lebih sehingga bisa menggunakan daun salam sebagai alternatif obat dalam mengatasi keluhan ataupun penyakit.Taksonomi daun salam dapat diklasifikasikan sebagai berikut yaitu dari family myrtaceae, genus syzygium dan species yaitu Syzygium polyanthum (Wight) (Mayasari, Anggitasari, and Isnawati 2020).

Masyarakat sebagai sasaran dalam kegiatan pengabdian masyarakat terutama ibu rumah tangga. Ibu rumah tangga merupakan kelompok non produktif yang akan dibekali ilmu dengan harapan ilmu tersebut bermanfaat dan diterapkan dalam kehidupan sehari-hari. Kegiatan edukasi diberikan kepada ibu rumah tangga diawali dengan pemaparan materi guna sebagai dasar pembelajaran akan dasar dari tanaman daun salam, selanjutnya diperagakan dengan tanaman daun salam itu sendiri secara daring dan dilanjutkan dengan diskusi serta tanya jawab sebagai respon yang diberikan oleh pemateri (Ferasinta et al. 2020).

Pengetahuan adalah sekumpulan fakta, kebenaran dan informasi yang diperoleh melalui pengalaman. Informasi yang diperoleh diharapkan dapat dipahami dan diterapkan sesuai kaidahnya. Edukasi yang diberikan kepada masyarakat dengan tujuan dapat meningkatkan pengetahuan sehingga dapat menerapkan pengetahuan. Daun salam dapat digunakan sebagai alternatif obat yang ramah lingkungan dan mudah didapatkan di lingkungan sekitar (Syah, Pujiyanti, and Widyantoro 2019). Dengan nilai yang ekonomis mampu mengatasi keluhan atau symptom dari berbagai keluhan masayarakat terkait khasiat daun salam. Edukasi dengan menggunakan tanaman daun salam diharapkan dapat meningkatkan pengetahuan masyarakat disekitar. 


\section{Metode}

Kegiatan edukasi khasiat daun salam dilakukan secara daring pada hari Sabtu, 12 Oktober 2019 dihadiri oleh 20 orang ibu rumah tangga dengan usia 20 sampai 30 tahun. Kegiatan ini dilakukan secara daring diawali dengan perkenalan, pemaparan materi, diskusi dan tanya jawab. Perkenalan diawali oleh pemateri dengan memperkenalkan diri dan menyebutkan tujuan kegiatan, kemudian dilanjutkan dengan perkenalan diri dari peserta. Pemaparan materi diberikan dengan menjelaskan daun salam dan komponen serta khasiat daun salam tersebut. Pemaparan materi diberikan secara daring dengan media zoom, pemaparan materi diikuti dengan membawa daun salam untuk diperagakan. Dalam pemaparan materi yang dijelaskan diantaranya adalah taksonomi daun salam, kandungan daun salam, penelitian sebelumnya dan khasiat daun salam. Diskusi dilakukan setelah pemaparan materi berlangsung, peserta diberi kesempatan untuk bertanya secara langsung, respon pemateri terhadap beberapa pertanyaan yang diberikan oleh peserta berlangsung dengan lancar dan mampu memberikan jawaban yang diharapkan oleh peserta. Tanya jawab merupakan respon yang diharapkan dalam kegiatan, sehingga diharapkan dengan adanya umpan balik tersebut memberikan nilai pemahaman untuk peserta.

\section{Hasil dan Pembahasan}

Hasil dari kegiatan pengabdian masyarakat yang dilaksanakan dengan judul Edukasi khasiat daun salam (Syzygium polyanthum) (Wight) Walp sebagai upaya peningkatan pengetahuan masyarakat adalah terdapat sejumlah 20 orang (ibu rumah tangga) 100\% yang mengikuti kegiatan, Dalam kegiatan diskusi dan tanya jawab terdapat beberapa pertanyaan dari peserta yang mengasah pemahaman dari materi yang disampaikan, peningkatan pengetahuan masyarakat akan edukasi ini diukur dengan adanya beberapa pertanyaan yang disampaikan oleh peserta dan jawaban yang diberikan oleh pemateri. Kegiatan pre-test dan post test juga diberikan diawal pertemuan dan diakhir pertemuan, dari hasil tersebut dapat dianalisis dengan adanya edukasi secara daring dapat meningkatkan pengetahuan peserta.Hasil peningkatan pengetahuan ibu rumah tangga tentang khasiat daun salam rerata adalah 96\%. Dari hasil kegiatan ini adalah sejumlah 20 orang (ibu rumah tangga menjadi paham akan khasiat daun salam selain sebagai bumbu masakan. Ibu rumah tangga diharapkan dapat menerapkan ilmu tersebut dalam kehidupan sehari hari. Daun salam dapat digunakan sebagai alternatif obat bagi masyarakat yang cost effective dan ramah lingkungan dengan khasiat sebagai antihipertensi, antidiabetes, antihiperkolesterol, mengatasi asam urat, dan sebagainya (Meirista Aulia; Lestari, 2020). Berikut adalah salah satu gambar kegiatan yang dilakukan secara daring dengan zoom dapat dilihat pada gambar 1. 


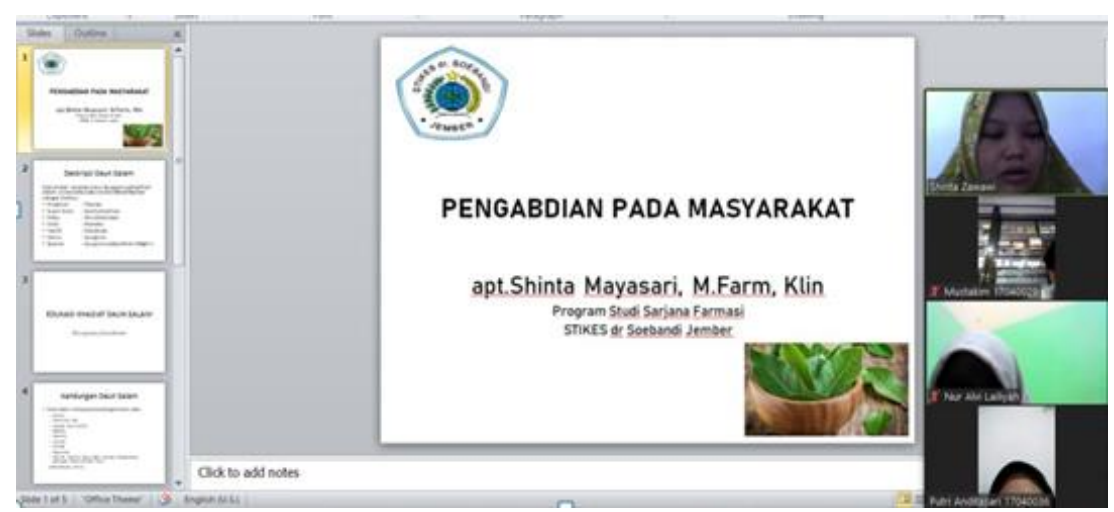

Gambar 1. Kegiatan pengabdian masyarakat secara daring

Hasil dari kegiatan pengabdian masyarakat dapat dilihat pada tabel distribusi dibawah ini

Tabel 1. Hasil Distribusi Frekuensi Pengabdian Masyarakat

\begin{tabular}{cccc}
\hline NO & Jenis Kelamin & Frekuensi & \% \\
\hline 1 & Perempuan & 20 & 100 \\
\hline
\end{tabular}

Tabel 2. Hasil Pengukuran Peningkatan Pengetahuan Ibu Rumah Tangga

\begin{tabular}{llccc}
\hline No & Jenis Kelamin & Pre-Test & Post-Test & $\begin{array}{c}\text { Hasil Peningkatan } \\
\text { Pengetahuan (\%) }\end{array}$ \\
\hline 1 & Perempuan & 40 & 80 & 100 \\
2 & Perempuan & 50 & 90 & 90 \\
3 & Perempuan & 40 & 80 & 100 \\
4 & Perempuan & 40 & 80 & 100 \\
5 & Perempuan & 30 & 70 & 100 \\
6 & Perempuan & 40 & 80 & 100 \\
7 & Perempuan & 50 & 90 & 90 \\
8 & Perempuan & 40 & 80 & 100 \\
9 & Perempuan & 30 & 80 & 100 \\
10 & Perempuan & 40 & 80 & 100 \\
11 & Perempuan & 50 & 90 & 90 \\
12 & Perempuan & 30 & 80 & 100 \\
13 & Perempuan & 40 & 80 & 100 \\
14 & Perempuan & 40 & 80 & 100 \\
15 & Perempuan & 50 & 90 & 100 \\
16 & Perempuan & 40 & 80 & 100 \\
17 & Perempuan & 40 & 80 & 100 \\
18 & Perempuan & 30 & 80 & 100 \\
19 & Perempuan & 30 & 80 & 100 \\
20 & Perempuan & 40 & 90 & \\
\hline
\end{tabular}

Dari kegiatan pengabdian masyarakat yang dilakukan secara daring via zoom dapat berjalan dengan lancar, peserta yaitu ibu rumah tangga memberikan respon umpan balik kepada pemateri terkait dengan tema khasiat daun salam. Pre-test dan post-test berjalan 
dengan baik, dan memberikan nilai yang memuaskan dapat dilihat dari kenaikan nilai posttest yang menunjukkan pemahaman ibu rumah tangga. Dengan edukasi, wawasan ibu rumah tangga menjadi lebih baik dan harapanya ilmu dapat diterapkan dalam kehidupan sehari-hari.

\section{Kesimpulan}

Kegiatan pengabdian masyarakat yang berjudul Edukasi khasiat daun salam (Syzygyum polyanthum) [Wight] (Walp) sebagai upaya peningkatan pengetahuan masyarakat dapat berjalan dengan lancar dan sesuai dengan harapan yaitu pengetahuan masyarakat semakin meningkat dari kegiatan edukasi tersebut. Daun salam tidak hanya digunakan sebagai bumbu masakan, namun bisa digunakan sebagai alternatif obat yang ramah lingkungan.

\section{Ucapan Terima Kasih}

Ucapan terimakasih disampaikan kepada pihak yang terlibat yaitu ibu rumah tangga di RT 05 RW 14 di Perumahan Kabupaten Jember, dan mahasiswa program studi farmasi yang membantu dalam acara kegiatan secara daring.

\section{Referensi}

Ferasinta, Lussyefrida,Y., Eva, O., \& Panzilion, P.( 2020). "Iptek Bagi Masyarakat: Pemberdayaan Masyarakat Dalam Penatalaksanaan Hipertensi Pada Lansia Untuk Menciptakan Lansia Sehat Dan Mandiri(Pemanfaatan Rebusan Air Daun Syzgium Polyanthum)." Jurnal Pengabdian Masyarakat Bumi Raflesia 3(2):343-50. doi: 10.36085/jpmbr.v3i2.823.

Mayasari, S., W. Anggitasari, \& N. Isnawati. (2020). "The Examination Activity of Salam Leaf Ethanolic Ekstract (Syzygium Polyanthum)[Wight] in Mice." Health Media 1(2):50-55.

Meirista, A., Lestari, Nyimas, I., Siregar, Sindy, F., \& Fitri.( 2020). "Pemanfaatan Bahan Herbal Dalam Upaya Pengendalian Hipertensi Melalui Penyuluhan Dan Pembuatan Produk Teh Daun Salam.” JMM (Jurnal Masyarakat Mandiri) 4(Vol 4, No 2 (2020): JUNI):300-307.

Nurdiwaty, Dian K., \& Puji. (2017). "Pemberdayaan Wanita Melalui Tanaman Toga Untuk Membantu Meningkatkan Pendapatan Keluarga." 1(1):20-27.

Syah, Devi, P., \& Tri, W. (2019). "Pemberdayaan Daun Salam Sebagai Tanaman Herbal" Universitas Muhammadiyah Magelang. 4-11.

Wirawan, W.(2018). "Uji Efektivitas Fraksi Daun Salam Terhadap Kadar Kolesterol Total Tikus Putih Jantan Hiperkolesterolemia-Diabetes." Jurnal Mandala Pharmacon Indonesia 4(1):74-82. doi: 10.35311/jmpi.v4i1.27. 